\title{
A novel synthetic approach to the thiotetronic ring system, the key intermediate for thiolactomycin analogues
}

\author{
Stefanos Kikionis, Kyriakos C. Prousis, Anastasia Detsi, and Olga Igglessi-Markopoulou* \\ National Technical University of Athens, School of Chemical Engineering, Laboratory of \\ Organic Chemistry, Zografou Campus, Athens 15773, Greece \\ E-mail: ojmark@orfeas.chemeng.ntua.gr
}

\begin{abstract}
The thiotetronic ring system is the key intermediate for the synthetic approach to thiolactomycin analogues. A novel one-pot synthesis of the thiotetronic ring system is described. The proposed methodology is based on a $C$-acylation/cyclization reaction between the $N$-hydroxysuccinimide esters of S-acetyl-thioglycolic acids and the appropriate active methylene compounds. ${ }^{1} \mathrm{H}$ and ${ }^{13} \mathrm{C}$ NMR spectroscopic data for the synthesized thiotetronic acids and 2-aminothiophenones are presented.
\end{abstract}

Keywords: thiotetronic acids, 2-aminothiophenones, thiolactomycin, C-acylation, tautomerism

\section{Introduction}

The basic heterocyclic thiolactone ring system is an integral part of a number of naturally occurring thiotetronic acids (Figure 1) possessing a wide range of biological activities.

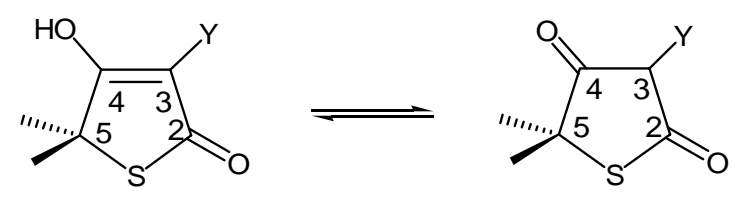

Figure 1. Thiotetronic ring system.

Thiolactomycin (TLM, Figure 2), an antibiotic isolated from Nocardia sp., is a unique thiolactone containing molecule that exhibits potent in vitro activity against many pathogenic bacteria ${ }^{1}$ including Gram positive and Gram negative bacteria and M. tuberculosis. Additionally, TLM acts as a selective and reversible inhibitor of the $\beta$-ketoacyl synthase (KAS) in the dissociated type II bacterial fatty acid synthase (FAS) systems including KAS I-III. ${ }^{2,3}$ Vastly 
higher levels of FAS are expressed in many human cancers and tumor cells. ${ }^{4,5}$ Furthermore TLM and its analogues are attractive leads for new drugs against malaria., ${ }^{6,7}$

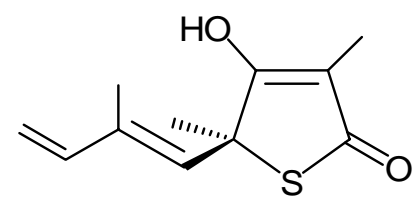

Figure 2. Thiolactomycin.

The wide range of biological properties and the potency for pharmaceutical applications have attracted considerable interest on the development of general methods for the synthesis of this group of heterocyclic molecules. The thiotetronic ring system is the key intermediate for the construction of thiolactomycin analogues. It is known that C-3 acyl analogues of TLM with C-5 aryl or alkyl functionalities display effective activities against Staphylococcus aureus and Pasteurella multicoda. ${ }^{8}$ For these reasons, thiotetronic acids represent an excellent target for a number of research groups, and several procedures for the preparation of these compounds have appeared in the literature.

The first synthetic approach for the construction of 3-substituted thiotetronic acids was reported by Benary ${ }^{9}$ in 1913 in which thiolactic acid chlorides were used as acylating agents of active methylene compounds. A similar method has been applied for the synthesis of various thiotetronic acids. $^{10,11}$

The first synthetic method for the racemic TLM analogues was developed by Salvino ${ }^{12}$ starting from $\alpha$-propionylpropionate as precursor by a three-step procedure. Significant studies in this area have been made by Thomas et al. ${ }^{13}$ who described an asymmetric synthesis of 5,5'disubstituted thiotetronic acids using a [3,3] rearrangement of an allyl xanthane to the corresponding dithiocarbonate. Recently, Townsend et al. ${ }^{14}$ described a flexible route to (5R)thiolactomycin employing Seebach's self-regenaration of chirality method. This method utilizes amino acids as chiral building blocks which were converted into the corresponding oxothiolactone and the synthesis was completed using a thio-Dieckmann condensation of the opened oxothiolactone ring under controlled conditions.

Moreover Gilbert et al. ${ }^{6,7}$ have synthesized a number of TLM analogues and undertook a complete structure activity relationships (SAR) study. The synthetic strategy is comprised of alkylation at the $\mathrm{C}-2$ of functionalized propionates followed by bromination and conversion to thiotetronic acids. A synthesis of new 4-substituted thiolactones is described by Kamal et al. ${ }^{2} \mathrm{~A}$ four-step procedure starting from achiral and chiral 4-pyrrolidinyl-2-thiophenones, followed by $\gamma$-alkylation reaction has been applied to the synthesis of thiolactomycin analogues. ${ }^{15}$

Besra et al. have synthesized several TLM derivatives with acetylene-based side chains which exhibited the highest recorded activity against cloned mtFabH condensing enzymes. ${ }^{16}$ Moreover, analogues bearing biphenyl-based substituents at the 5-position showed excellent in 
vitro inhibitory activity against $M$. tuberculosis $\beta$-ketoacyl-ACP synthase $\mathrm{mFabH}$ condensing enzyme, compared to TLM. ${ }^{17}$ These results demonstrate the importance of the functional groups at the 5-position of the thiolactone ring.

In the course of our research programme on the use of enolic $\beta$-dicarbonyl compounds for the synthesis of tetronic ${ }^{18,19}$ and tetramic acids ${ }^{20-22}$ and 2-amino-3-substituted heterocyclic compounds, ${ }^{23,24}$ we have developed a new synthetic sequence for the construction of functionalized thiotetronic acids. In this paper we present a new synthetic approach to thiotetronic acid analogues bearing various functional groups at the $\mathrm{C}-3\left(\mathrm{COR}, \mathrm{CO}_{2} \mathrm{R}\right)$ and $\mathrm{C}-5$ (alkyl) positions of the thiolactone ring.

\section{Results and Discussion}

The proposed methodology for the synthesis of thiotetronic acids involves the use of $\mathrm{N}$ hydroxysuccinimide esters of S-acetylthioglycolic acids 5, 6 and active methylene compounds 711 as building blocks bearing appropriate substituents suitable for preparing highly functionalized thiotetronic acids and 2-aminothiophenones 13-20. (Scheme 1)

The N-hydroxysuccinimide esters of S-acetylthioglycolic acids are easily prepared in high yields and are efficient acylating agents. The N-hydroxysuccinimide formed as a by-product, during the $\mathrm{C}$-acylation reaction, is soluble in water and therefore easily removed from the reaction mixture. ${ }^{25}$

In this work we have attempted to combine ease of operation, short reaction times and mild reaction conditions. The "mild conditions" employed in the one-pot C-acylation/cyclization reaction allowed a variety of functionalities to be incorporated into the thiolactone moiety.

In a typical $\mathrm{C}$-acylation reaction, active methylene compounds 7-11 bearing appropriate substituents react with the N-hydroxysuccinimide esters 5, 6 of S-acetyl-protected thioglycolic acids 3,4 . The (non isolated) C-acylation intermediates 12 undergo an in situ cyclization reaction to afford either the 3 -substituted thiotetronic acids $13,14,15,16$ or the 2-aminothiophenones 17 , 18, 19, 20 via an intramolecular condensation mechanism (Scheme 1). 
<smiles>[R]C(S)C(=O)O</smiles>

$\frac{1}{2} \mathrm{R}=\stackrel{\mathrm{M}}{\mathrm{Me}}$

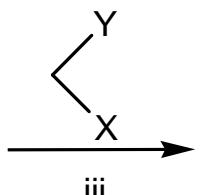

$\mathrm{Y}=$ COOMe $\mathrm{X}=$ COOMe

$8 \mathrm{COPh} \quad \mathrm{COOEt}$

9 COPr COOEt

$10 \mathrm{CN}$ COOMe

$11 \mathrm{CN} \quad \mathrm{CN}$

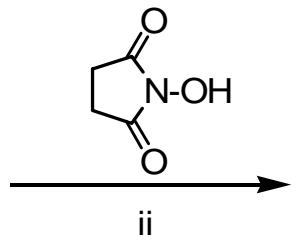

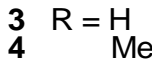<smiles>[R]C([Se])C(=O)ON1C(=O)CCC1=O</smiles>

$5 \mathrm{R}=\mathrm{H}$

Scheme 1. Reagents and conditions: i, $\mathrm{Et}_{3} \mathrm{~N}$, dioxane; ii, $\mathrm{CH}_{2} \mathrm{Cl}_{2}, \mathrm{DCC}$; iii, $\mathrm{NaH}$, THF.

Attempted preparation of 3-cyanothiotetronic acids by coupling N-hydroxysuccinimide esters 5, 6 of S-acetylthioglycolic acids 3, 4 with methyl cyanoacetate led to 2aminothiophenones 17, 18 (Scheme 2).

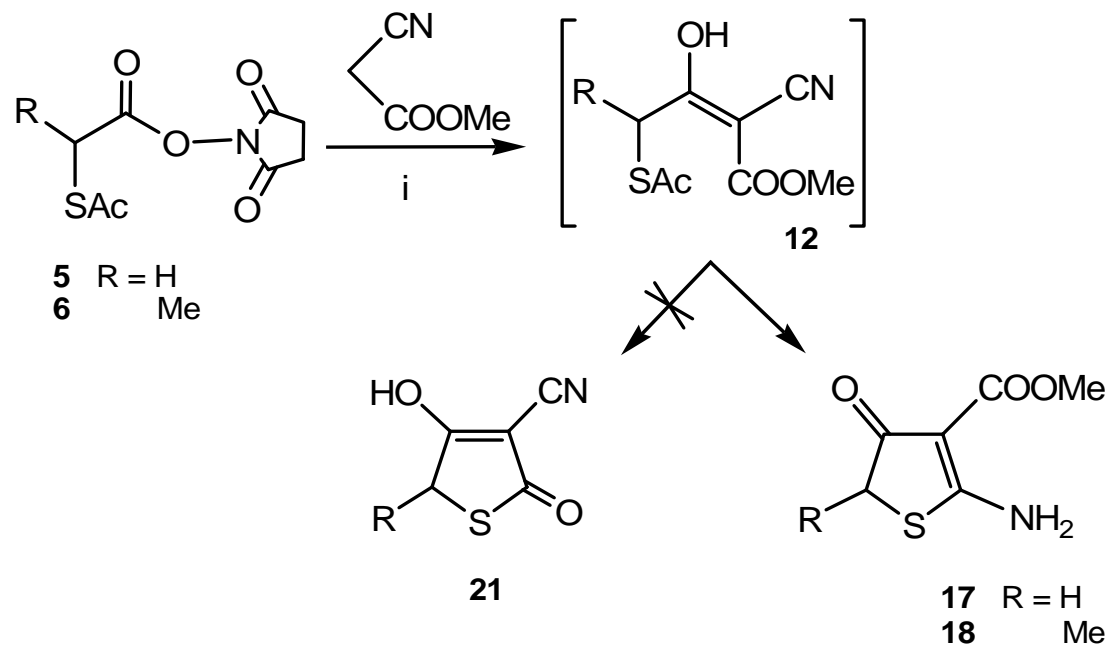

Scheme 2. Reagents and conditions: i, NaH, THF. 
The synthetic protocol reported here represents the first example of the synthesis for 2aminothiophenones 17, 18, 19, 20 by direct cyclization of the non isolated intermediate 12. Compounds bearing the 2-amino-thiophenone moiety have been previously prepared and are useful as intermediates for the synthesis of dyes and agrochemicals. ${ }^{26-29}$

The structures of the prepared compounds were confirmed by elemental analysis and their NMR spectral data. In the ${ }^{1} \mathrm{H}$ NMR spectrum of S-acetylthioglycolic acid (3) the two singlet signals for $\mathrm{COCH}_{3}$ group are attributed to the hindered rotation around the S-C bond. ${ }^{30}$

The structure of thiotetronic acids and 2-aminothiophenones has been elucidated by ${ }^{1} \mathrm{H}$ and ${ }^{13} \mathrm{C}$ NMR spectroscopy (see experimental). The 3 -substituted thiotetronic acids 13, 14, 15, 16, were found to exist in $\mathrm{CDCl}_{3}$ solution in the enolized form. The ${ }^{1} \mathrm{H}$ NMR spectra lacked any resonance characteristic of a methine proton at $\mathrm{C}-3$, corresponding to the keto form, whereas in their ${ }^{13} \mathrm{C}$ NMR spectra there was no signal attributable to an $\mathrm{sp}^{3}-\mathrm{CH}$ form at $\mathrm{C}-3$ for the 4-ketothiolactone structure.

In the spectra of thiotetronic acids bearing an alkoxycarbonyl group at position-3 only one set of signals was observed for all protons in $\mathrm{CDCl}_{3}$ solution. On the other hand, two sets of signals are present in the ${ }^{1} \mathrm{H}$ and ${ }^{13} \mathrm{C}$ NMR spectra of the 3-butanoylthiotetronic acid (16) in $\mathrm{CDCl}_{3}$, indicating the existence of the "external" tautomers $\mathrm{AB}$ and $\mathrm{CD}$ (Figure 3) with an integral ratio of $\mathrm{AB} / \mathrm{CD}=1 / 0.17$.

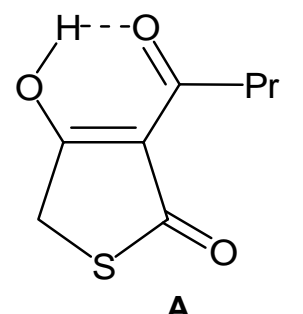

A

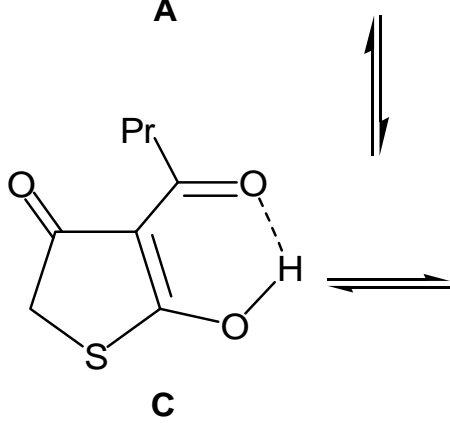

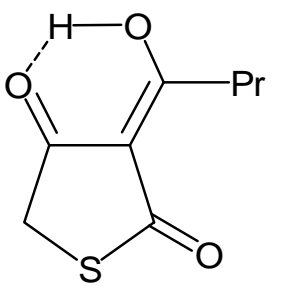

B

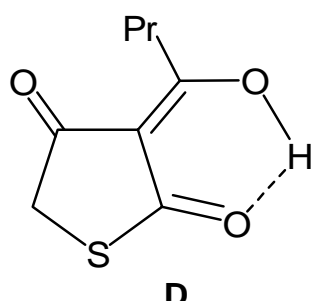

Figure 3. Enol-enol equilibrium of the 3-butanoylthiotetronic acid (16).

These results are in accordance with the tautomeric observations on the analogous tetronic acids $[\mathrm{AB} / \mathrm{CD}=1 / 0.67]^{19}$ whereas for the equivalent $\mathrm{NH}$-tetramic acids the dominant form is the "external" pair of tautomers $\mathrm{CD}[\mathrm{CD} / \mathrm{AB}=3.55] .{ }^{31}$ 
The ${ }^{13} \mathrm{C}$ NMR assignments of 3-butanoylthiotetronic acid (16) have been made by comparison with the values of these carbon atoms established for the corresponding 3-acetyland 3-butanoyl-tetramic acids. ${ }^{31}$

In conclusion, a novel, concise route to functionalized thiotetronic acid analogues is described. The methodology is comprised of a $\mathrm{C}$-acylation/cyclization reaction, providing the desired compounds in high yields. Moreover, the developed synthetic route is easily scaled-up and can be useful for the synthesis of compounds bearing a wide variety of substituents on positions 3 and 5 of the thiotetronic ring.

\section{Experimental Section}

General Procedures. Mps were determined on a Gallenkamp MFB-595 melting point apparatus and are uncorrected. The NMR spectra were recorded on a Varian Gemini-2000 $300 \mathrm{MHz}$ and a Bruker AC $300300 \mathrm{MHz}$ spectrometer; chemical shifts are quoted in ppm (s = singlet, $\mathrm{d}=$ doublet, $\mathrm{t}=$ triplet, $\mathrm{q}=$ quartet, $\mathrm{m}=$ multiplet, $\mathrm{br}=$ broad); $J$ values are given in Hz. Elemental analyses were obtained on a Euro EA3000 Series Euro Vector CHNS Elemental Analyser. Petroleum ether refers to the fraction with $b p\left(40-60{ }^{\circ} \mathrm{C}\right)$. Commercially available THF was dried prior to use by refluxing over $\mathrm{Na}$. All other solvents (puriss quality) were used without further purification. Origin and purity of the other reagents are as follows: thiolactic acid, techn; thioglycolic acid, purum; N-hydroxysuccinimide, purum; DCC, puriss.

\section{General Procedure for the Synthesis of S-Acetyl-thioglycolic acids ${ }^{32}$}

A solution of the appropriate thioglycolic acid 1, $2(10 \mathrm{mmol})$ in dioxane $(5 \mathrm{~mL})$ was cooled in an ice- $\mathrm{H}_{2} \mathrm{O}$ bath and triethylamine $(3.05 \mathrm{~mL})$ was slowly added under argon. Acetyl chloride (11 mmol) was then added dropwise at $0{ }^{\circ} \mathrm{C}$ and the resulting solution was stirred at room temperature overnight. The precipitated solid ( $\mathrm{Et}_{3} \mathrm{~N}$-salt) was filtered off and the filtrate was concentrated to give an oily product. Hydrochloric acid (5\%) was added and the solution was allowed to stir for $1 \mathrm{~h}$ at $0{ }^{\circ} \mathrm{C}$. The resulting mixture was extracted twice with dichloromethane and the combined organic layers were dried over anhydrous $\mathrm{Na}_{2} \mathrm{SO}_{4}$, concentrated under reduced pressure and dried in vacuo to afford the corresponding $S$-acetylthioglycolic acids 3, 4 as oily products.

General Procedure for the Synthesis of $N$-Hydroxysuccinimide esters of $S$ acetylthioglycolic acids

In a typical reaction, the appropriate $S$-acetyl-thioglycolic acid 3, 4 (10 mmol) was treated under argon with $N$-hydroxysuccinimide $(10 \mathrm{mmol}, 1.16 \mathrm{~g})$ in dichloromethane $(11.5 \mathrm{~mL})$. A solution of DCC (12 mmol, 2,47 g) in dichloromethane $(8.5 \mathrm{ml})$ was then added dropwise at $0{ }^{\circ} \mathrm{C}$ and the reaction mixture was allowed to stir at $0{ }^{\circ} \mathrm{C}$ for $2 \mathrm{~h}$. The resulting suspension was refrigerated overnight at $3-5{ }^{\circ} \mathrm{C}$. The precipitated solid (DCCU) was filtered off and discarded and the dichloromethane filtrate was evaporated under reduced pressure and dried in vacuo to afford the 
$N$-hydroxysuccinimide esters 5, 6 of the corresponding S-acetylthioglycolic acids as oily products.

General Procedure for the Synthesis of 3,5-Substituted-thiotetronic acids and 2-amino-3,5substituted-4-thiophenones

$\mathrm{NaH}$ (60\% suspension in oil) (20mmol, $0.8 \mathrm{~g})$ was added in anhydrous $\mathrm{THF}(65 \mathrm{~mL})$ at $0{ }^{\circ} \mathrm{C}$ and the resulting mixture was stirred under argon for $15 \mathrm{~min}$ at room temperature. The appropriate active methylene compound 7-11 (dimethyl malonate, ethyl benzoylacetate, ethyl butyrylacetate, methyl cyanoacetate and malonitrile) $(30 \mathrm{mmol})$ was then added at $0{ }^{\circ} \mathrm{C}$ and after a period of $1 \mathrm{~h}$ stirring at room temperature, the $N$-hydroxysuccinimide ester 5,6 was added. The reaction mixture was allowed to stir at room temperature for $2 \mathrm{~h}$ or $4 \mathrm{~h}$ and then concentrated under reduced pressure. The obtained gummy solid was diluted with $\mathrm{H}_{2} \mathrm{O}(10 \mathrm{~mL})$ and washed with $\mathrm{Et}_{2} \mathrm{O}(5 \mathrm{~mL})$. The aqueous extract was acidified with aqueous $\mathrm{HCl}(10 \%)$ in an ice- $\mathrm{H}_{2} \mathrm{O}$ bath to afford an oily product, which was extracted with $\mathrm{CH}_{2} \mathrm{Cl}_{2}(3 \times 15 \mathrm{~mL})$ and the combined organic layers were dried over anhydrous $\mathrm{Na}_{2} \mathrm{SO}_{4}$, concentrated under reduced pressure dried in vacuo and the oily residue was treated with dichloromethane, diethyl ether or petroleum ether to afford as solids the corresponding 3,5-substituted-thiotetronic acids 13, 14, 15, 16 and 2-amino-3,5substituted-4-thiophenones 17, 18, 19, 20.

\section{Compound Characterization}

S-Acetylthioglycolic acid (3). Yellow oil. Yield: (95\%)

${ }^{1} \mathrm{H} \mathrm{NMR}\left(\mathrm{CDCl}_{3}\right): \delta=2.39 / 2.41\left(2 \mathrm{~s}, 3 \mathrm{H}, \mathrm{COCH}_{3}\right), 3.72\left(\mathrm{~s}, 2 \mathrm{H}, \mathrm{CH}_{2}\right), 9.2\left(\mathrm{br} \mathrm{s}, 1 \mathrm{H}, \mathrm{CO}_{2} \mathrm{H}\right)$.

S-Acetylthiolactic acid (4). Yellow oil. Yield: (90\%)

${ }^{1} \mathrm{H}$ NMR $\left(\mathrm{CDCl}_{3}\right): \delta=1.50\left(\mathrm{~d}, J=7.2 \mathrm{~Hz}, 3 \mathrm{H}, \mathrm{CHCH}_{3}\right), 2.35\left(\mathrm{~s}, 3 \mathrm{H}, \mathrm{COCH}_{3}\right), 4.21(\mathrm{q}, J=7.2$ $\mathrm{Hz}, 1 \mathrm{H}, \mathrm{CH}), 9.78$ (br s, $1 \mathrm{H}, \mathrm{CO}_{2} \mathrm{H}$ ).

$\boldsymbol{N}$-Hydroxysuccinimide ester of $\boldsymbol{S}$-acetylthioglycolic acid (5). Yellow oil. Yield: $(90 \%)$

${ }^{1} \mathrm{H} \mathrm{NMR}\left(\mathrm{CDCl}_{3}\right): \delta=2.36\left(\mathrm{~s}, 3 \mathrm{H}, \mathrm{COCH}_{3}\right), 2.82\left(\mathrm{~s}, 4 \mathrm{H}, \mathrm{CH}_{2} \mathrm{CH}_{2}\right), 3.96\left(\mathrm{~s}, 2 \mathrm{H} \mathrm{CH}_{2}\right)$.

$\boldsymbol{N}$-Hydroxysuccinimide ester of $\boldsymbol{S}$-acetylthiolactic acid (6). Yellow oil. Yield: $(89 \%)$

${ }^{1} \mathrm{H} \mathrm{NMR}\left(\mathrm{CDCl}_{3}\right): \delta=1.62\left(\mathrm{~d}, J=7.5 \mathrm{~Hz}, 3 \mathrm{H}, \mathrm{CHCH}_{3}\right), 2.37\left(\mathrm{~s}, 3 \mathrm{H}, \mathrm{COCH}_{3}\right), 2.82(\mathrm{~s}, 4 \mathrm{H}$, $\left.\mathrm{CH}_{2} \mathrm{CH}_{2}\right), 4.51$ (q, $\left.J=7.5 \mathrm{~Hz}, 1 \mathrm{H}, \mathrm{CHCH}_{3}\right)$

3-Methoxycarbonylthiotetronic acid (13). Starting from thioglycolic acid (1) and using dimethyl malonate (7) as the active methylene compound, after $2 \mathrm{~h}$ stirring and treatment with diethyl ether, compound 13 was obtained as a yellow solid. Yield: (75\%); mp 192-194 ${ }^{\circ} \mathrm{C}$ (lit. 201-204 $\left.{ }^{\circ} \mathrm{C}\right) .{ }^{33}$

${ }^{1} \mathrm{H} \mathrm{NMR}\left(\mathrm{CDCl}_{3}\right): \delta=3.95\left(\mathrm{~s}, 3 \mathrm{H}, \mathrm{CO}_{2} \mathrm{CH}_{3}\right), 4.03\left(\mathrm{~s}, 2 \mathrm{H}, \mathrm{CH}_{2}\right), 13.87$ (br s, $\left.1 \mathrm{H}, \mathrm{OH}\right)$.

${ }^{13} \mathrm{C} \mathrm{NMR}\left(\mathrm{CDCl}_{3}\right): \delta=32.73\left(\mathrm{CO}_{2} \mathrm{CH}_{3}\right), 52.16(\mathrm{C}-5), 105.02(\mathrm{C}-3), 167.26\left(\mathrm{CO}_{2} \mathrm{CH}_{3}\right), 190.51$ (C-2), 192.18 (C-4).

3-Methoxycarbonyl-5-methylthiotetronic acid (14). Starting from thiolactic acid (2) and using dimethyl malonate (7) as the active methylene compound, after $2 \mathrm{~h}$ stirring and treatment with diethyl ether, compound 14 was obtained as a white solid. Yield: (72\%), (Recrystallization from $\mathrm{CH}_{2} \mathrm{Cl}_{2}$-Petroleum); mp 114-116 ${ }^{\circ} \mathrm{C}$. 
${ }^{1} \mathrm{H} \mathrm{NMR}\left(\mathrm{CDCl}_{3}\right): \delta=1.69\left(\mathrm{~d}, J=7.2 \mathrm{~Hz}, 3 \mathrm{H}, \mathrm{CHCH}_{3}\right), 3.95\left(\mathrm{~s}, 3 \mathrm{H}, \mathrm{CO}_{2} \mathrm{CH}_{3}\right), 4.33$ (q, $J=7.2$ $\mathrm{Hz}, 1 \mathrm{H}, \mathrm{CHCH}_{3}$ ), 12.98 (br s, $\left.1 \mathrm{H}, \mathrm{OH}\right)$.

${ }^{13} \mathrm{C}$ NMR $\left(\mathrm{CDCl}_{3}\right): \delta=18.55\left(\mathrm{CH}_{3}\right), 42.96\left(\mathrm{CO}_{2} \mathrm{CH}_{3}\right), 52.92(\mathrm{C}-5), 104.32(\mathrm{C}-3), 168.64$ $\left(\mathrm{CO}_{2} \mathrm{CH}_{3}\right), 188.77(\mathrm{C}-2), 195.91(\mathrm{C}-4)$.

Anal. Calcd for $\mathrm{C}_{7} \mathrm{H}_{8} \mathrm{SO}_{4}$ (188): C, 44.67; H, 4.28; S, 17.04. Found: C, 44.72; H, 4.35; S, 17.15.

3-Benzoylthiotetronic acid (15). Starting from thioglycolic acid (1) and using ethyl benzoylacetate (8) as the active methylene compound, after $4 \mathrm{~h}$ stirring and treatment with dichloromethane and petroleum ether compound $\mathbf{1 5}$ was obtained as white solid. Yield: (85\%); mp $65-67^{\circ} \mathrm{C}\left(\right.$ lit. $\left.75-77^{\circ} \mathrm{C}\right) .{ }^{34}$

${ }^{1} \mathrm{H}$ NMR $\left(\mathrm{CDCl}_{3}\right): \delta=4.09$ (s, $\left.2 \mathrm{H}, \mathrm{CH}_{2}\right), 7.46-8.1(\mathrm{~m}, 5 \mathrm{H}$, aromatic $\mathrm{H})$.

${ }^{13} \mathrm{C}$ NMR $\left(\mathrm{CDCl}_{3}\right): \delta=35.34(\mathrm{C}-5), 109.46(\mathrm{C}-3), 128.09,128.63,130.01,130.34,133.92$, $133.98\left(\mathrm{C}_{6} \mathrm{H}_{5}\right), 172.06(\mathrm{C}-2), 191.04\left(\mathrm{COC}_{6} \mathrm{H}_{5}\right), 200.91(\mathrm{C}-4)$.

3-n-Butanoylthiotetronic acid (16). Starting from thioglycolic acid (1) and using ethyl butanoylacetate (9) as the active methylene compound, after $4 \mathrm{~h}$ stirring and treatment with petroleum ether, compound 16 was obtained as brown crystals. Yield: $(81 \%) ; \mathrm{mp} 69-70{ }^{\circ} \mathrm{C}$ (lit. $\left.71-72{ }^{\circ} \mathrm{C}\right) . .^{34}$

${ }^{1} \mathrm{H}$ NMR $\left(\mathrm{CDCl}_{3}\right): \delta=0.99\left(\mathrm{~m}, 3 \mathrm{H}, \mathrm{COCH}_{2} \mathrm{CH}_{2} \mathrm{CH}_{3}\right), 1.636-1.759\left(\mathrm{~m}, 2 \mathrm{H}, \mathrm{COCH}_{2} \mathrm{CH}_{2} \mathrm{CH}_{3}\right)$, 2.90-2.96 (m, 2H, $\mathrm{COCH}_{2} \mathrm{CH}_{2} \mathrm{CH}_{3}$ ), 3.76/3.98 (2s, 2H, $\left.\mathrm{CH}_{2}, \mathrm{CD} / \mathrm{AB}: 0.17 / 1\right), 16.09$ (br s, $1 \mathrm{H}$, $\mathrm{OH})$.

${ }^{13} \mathrm{C}$ NMR $\left(\mathrm{CDCl}_{3}\right): \delta=13.72\left(\mathrm{COCH}_{2} \mathrm{CH}_{2} \mathrm{CH}_{3} \mathrm{AB}\right), 18.06\left(\mathrm{COCH}_{2} \mathrm{CH}_{2} \mathrm{CH}_{3} \mathrm{AB}\right), 18.72$ $\left(\mathrm{COCH}_{2} \mathrm{CH}_{2} \mathrm{CH}_{3} \mathrm{CD}\right), 34.62\left(\mathrm{COCH}_{2} \mathrm{CH}_{2} \mathrm{CH}_{3} \mathrm{CD}\right), 35.24\left(\mathrm{COCH}_{2} \mathrm{CH}_{2} \mathrm{CH}_{3} \mathrm{AB}\right), 38.54(\mathrm{C}-5$ $\mathrm{AB}), \quad 39.21(\mathrm{C}-5 \quad \mathrm{CD}) \quad 107.10 \quad(\mathrm{C}-3 \quad \mathrm{CD}), 110.16 \quad(\mathrm{C}-3 \quad \mathrm{AB}), 191.65$ (C-2 $\mathrm{AB}) 192.81$ $\left(\mathrm{COCH}_{2} \mathrm{CH}_{2} \mathrm{CH}_{3} \mathrm{CD}\right), 193.20$ (C-4 CD), $198.99\left(\mathrm{COCH}_{2} \mathrm{CH}_{2} \mathrm{CH}_{3} \mathrm{AB}\right), 199.48$ (C-4 AB).

2-Amino-3-methoxycarbonyl-4-thiophenone (17). Starting from thioglycolic acid (1) and using methyl cyanoacetate (10) as the active methylene compound, after $2 \mathrm{~h}$ stirring and treatment with dichloromethane, compound $\mathbf{1 7}$ was obtained as a green solid. Yield: (72\%); mp $>300^{\circ} \mathrm{C}$.

${ }^{1} \mathrm{H}$ NMR (DMSO- $\left.d_{6}\right): \delta=3.51\left(\mathrm{~s}, 2 \mathrm{H}, \mathrm{CH}_{2}\right), 3.62\left(\mathrm{~s}, 3 \mathrm{H}, \mathrm{CO}_{2} \mathrm{CH}_{3}\right), 8.90(\mathrm{~s}, 1 \mathrm{H}, \mathrm{NH}), 9.43(\mathrm{~s}$, $1 \mathrm{H}, \mathrm{NH})$.

${ }^{13} \mathrm{C}$ NMR (DMSO- $\left.d_{6}\right): \delta=37.34\left(\mathrm{CO}_{2} \mathrm{CH}_{3}\right), 50.21(\mathrm{C}-5), 95.55(\mathrm{C}-3), 165.0\left(\mathrm{CO}_{2} \mathrm{CH}_{3}\right), 183.73$ (C-2), 190.89 (C-4).

Anal. Calcd for $\mathrm{C}_{6} \mathrm{H}_{7} \mathrm{NSO}_{3}$ (173): C, 41.61; H, 4.07; N, 8.09; S, 18.51. Found: $\mathrm{C}, 41.53 ; \mathrm{H}, 4.13$; N, 7.90; S, 18.39 .

2-Amino-3-methoxycarbonyl-5-methyl-4-thiophenone (18). Starting from thiolactic acid (2) and using methyl cyanoacetate (10) as the active methylene compound, after $2 \mathrm{~h}$ stirring and treatment with diethyl ether, compound $\mathbf{1 8}$ was obtained as a white solid. Yield: (88\%); mp 211$213^{\circ} \mathrm{C}$.

${ }^{1} \mathrm{H}$ NMR $\left(\mathrm{CDCl}_{3}\right): \delta=1.59\left(\mathrm{~d}, J=7.2 \mathrm{~Hz}, 3 \mathrm{H}, \mathrm{CHCH}_{3}\right), 3.82\left(\mathrm{q}, J=7.2 \mathrm{~Hz}, 1 \mathrm{H}, \mathrm{CHCH}_{3}\right), 3.84$ (s, $\left.3 \mathrm{H}, \mathrm{CO}_{2} \mathrm{CH}_{3}\right), 6.75(\mathrm{~s}, 1 \mathrm{H}, \mathrm{NH}), 9.18(\mathrm{~s}, 1 \mathrm{H}, \mathrm{NH})$. 
${ }^{13} \mathrm{C}$ NMR $\left(\mathrm{CDCl}_{3}\right): \delta=18.73\left(\mathrm{CH}_{3}\right), 48.28\left(\mathrm{CO}_{2} \mathrm{CH}_{3}\right), 51.45(\mathrm{C}-5), 96.75(\mathrm{C}-3), 166.62$ $\left(\mathrm{CO}_{2} \mathrm{CH}_{3}\right), 183.77(\mathrm{C}-2), 195.23(\mathrm{C}-4)$.

Anal. Calcd for $\mathrm{C}_{7} \mathrm{H}_{9} \mathrm{NSO}_{3}$ (187): C, 44.91; H, 4.84; N, 7.48; S, 17.13. Found: C, 44.83; H, 4.79; N, 7.53; S, 17.26.

2-Amino-3-cyano-4-thiophenone (19). Starting from thioglycolic acid (1) and using malonitrile (11) as the active methylene compound, after $2 \mathrm{~h}$ stirring and treatment with diethyl ether, compound 19 was obtained as a brown solid. Yield: $(92 \%) ; \mathrm{mp}>300{ }^{\circ} \mathrm{C}$ (lit. $\left.>300{ }^{\circ} \mathrm{C}\right) .{ }^{35}$

${ }^{1} \mathrm{H}$ NMR (DMSO-d $): \delta=3.85$ (s, 2H, $\left.\mathrm{CH}_{2}\right), 9.18$ (s, 1H, NH), 9.38 (s, 1H, NH).

${ }^{13} \mathrm{C}$ NMR (DMSO- $\left.d_{6}\right): \delta=38.80(\mathrm{C}-5), 79.72(\mathrm{C}-3), 114.54(\mathrm{CN}), 182.00(\mathrm{C}-2), 192.48(\mathrm{C}-4)$.

2-Amino-3-cyano-5-methyl-4-thiophenone (20). Starting from thiolactic acid (2) and using malonitrile (11) as the active methylene compound, after $2 \mathrm{~h}$ stirring and treatment with diethyl ether, compound 20 was obtained as a yellow solid. Yield: (93\%); mp 278-270 ${ }^{\circ} \mathrm{C}$.

${ }^{1} \mathrm{H}$ NMR (DMSO- $\left.d_{6}\right): \delta=1.47\left(\mathrm{~d}, J=7.2 \mathrm{~Hz}, 3 \mathrm{H}, \mathrm{CHCH}_{3}\right), 4.06\left(\mathrm{q}, J=7.2 \mathrm{~Hz}, 1 \mathrm{H}, \mathrm{CHCH}_{3}\right.$ ), $9.21(\mathrm{~s}, 1 \mathrm{H}, \mathrm{NH}), 9.38(\mathrm{~s}, 1 \mathrm{H}, \mathrm{NH})$.

${ }^{13} \mathrm{C}$ NMR (DMSO- $\left.d_{6}\right): \delta=18.13\left(\mathrm{CH}_{3}\right), 48.54(\mathrm{C}-5), 78.42(\mathrm{C}-3), 114.68(\mathrm{CN}), 180.47(\mathrm{C}-2)$, 195.38 (C-4).

Anal. Calcd for $\mathrm{C}_{6} \mathrm{H}_{6} \mathrm{~N}_{2} \mathrm{SO}$ (154): C, 46.74; H, 3.92; N, 18.17; S, 20.79. Found: C, 46.68; H, $4.05 ; \mathrm{N}, 18.24 ; \mathrm{S}, 20.83$.

\section{References and Footnotes}

1. Brown, M. S.; Akopiants, K.; Resceck, D. M.; McArthur, H. A. I.; McCormick, E.; Reynolds, K. A. J. Am. Chem. Soc. 2003, 125, 10166.

2. Kamal, A.; Shaik, A. A.; Sinha, R.; Yadav, J. S.; Arora, S. K. Bioorg. Med. Chem. Lett. 2005, 15, 1927.

3. Nie, Z.; Perretta, C.; Lu, J.; Su, Y.; Margosiak, S.; Gajiwala, K. S.; Cortez, J.; Nikulin, V.; Yager, K. M.; Applet, K.; Chu, S. J. Med. Chem. 2005, 48, 1596.

4. McFadden J. M.; Medghalchi, S. M.; Thupari, J. N.; Pinn, M. L.; Vadlamudi, A.; Miller, K. I.; Kuhajda, F. P.; Townsend, C. A. J. Med. Chem. 2005, 48, 946.

5. Kim, P.; Zhang Y.-M.; Shenoy, G.; Nguyen, Q.-A.; Boshoff, H. I.; Manjunatha, U. H.; Goodwin, M. B.; Lonsdale, J.; Price, A. C.; Miller, D. J.; Duncan, K.; White, S. W.; Rock, C. O.; Barry, C. E.; Dowd, C. S. J. Med. Chem. 2006, 49, 159.

6. Jones, S. M.; Urch, J. E.; Kaiser, M.; Brun, R.; Harwood, J. L.; Berry, C.; Gilbert, I. H. J. Med. Chem. 2005, 48, 5932.

7. Jones, S. M.; Urch, J. E.; Kaiser, M.; Brun, R.; Harwood, J. L.; Berry, C.; Gilbert, I. H. Bioorg. Med. Chem. 2004, 12, 683.

8. Sakya, S. M.; Suarez-Contreras, M.; Dirlam, J. P.; O’Connell, T. N.; Hayashi, S. F.; Santoro, S. L.; Kamicker, B. J.; George, D. M.; Ziegler, C. B. Bioorg. Med. Chem. Lett. 2001, 11, 2751. 
9. a) Benary, E. Ber. 1910, 43, 1943; b) Benary, E.; Ber. 1913, 46, 2103.

10. O' Mant, D. M. J. Chem. Soc. Perkin Trans. 1 1968, 12, 1501.

11. Budnikova, M. V.; Rubinov, D. B. Russ. J. Org. Chem. 2001, 37, 1478.

12. Wang, C.-L. J.; Salvino, J. M. Tetrahedron Lett. 1984, 25, 5243.

13. Chambers, M. S.; Thomas, E. J. J. Chem. Soc., Perkin Trans. 1 1997, 417.

14. Mc Fadden, J. M.; Frehywot, G. L.; Townsend, C. A. Org. Lett. 2002, 4, 3859.

15. Li, Y.-J.; Liu, Z.-T.; Yang, S.-C. Tetrahedron Lett. 2001, 42, 8011.

16. Senior, S. J.; Illarionov, P. A.; Gurcha, S. S.; Campbell, I. B.; Schaeffer, M. L.; Minnikin, D. E.; Besra, G. S. Bioorg. Med. Chem. Lett. 2004, 14, 373.

17. Senior, S. J.; Illarionov, P. A.; Gurcha, S. S.; Campbell, I. B.; Schaeffer, M. L.; Minnikin, D. E.; Besra, G. S. Bioorg. Med. Chem. Lett. 2003, 13, 3685.

18. Mitsos, C.; Zografos, A.; Igglessi-Markopoulou, O. J. Org. Chem. 2000, 65, 5852.

19. Athanasellis, G.; Igglessi-Markopoulou, O.; Markopoulos, J. Synlett 2002, 1736.

20. Detsi, A.; Markopoulos, J.; Igglessi-Markopoulou, O. Chem. Commun. 1996, 1323.

21. Petroliagi, M.; Igglessi-Markopoulou, O. Tetrahedron Asymmetry, 1999, 10, 1873.

22. Athanasellis, G.; Gavrielatos, E.; Igglessi-Markopoulou, O. Synlett 2001, 10, 1653.

23. Prousis, K.C. ; Detsi A. ; Igglessi-Markopoulou O. Synlett, 2005, 18, 2763.

24. Athanasellis, G.; Melagraki, G.; Afantitis, A.; Makridima, K.; Igglessi-Markopoulou, O., ARKIVOC, 2006, 28.

25. Katritzky, A.; Suzuki, K.; Singh, S.K., ARKIVOC, 2004, 12.

26. Jpn. Kokai Tokkyo Koho, JP 59042376, 1984; Chem. Abstr. 1984, 100, 211664.

27. Heinz, E. K. Ger. Offen. DE 3630070, 1988; Chem. Abstr. 1988, 109, 190235.

28. Robert, E.; Beat, H. Ger. Offen. DE 3529831, 1986; Chem. Abstr. 1987, 106, 6402.

29. Naoto, I.; Hiroshi, A.; Masumi, N.; Naoyuki, Y.; Takeshi, N.; Tatsuya, N. Jpn. Kokai Tokkyo Koho, 1985; Chem. Abstr. 1986, 104, 88420.

30. Günther, H. NMR Spectroscopy, John Wiley \& Sons, 1980, p.247.

31. Barkley, V.; Markopoulos, J.; Markopoulou, O. J. Chem. Soc., Perkin Trans 2, 1994, 1271.

32. Musser, J. H.; Bailey, K.; Suh, J. T. Heterocycles 1985, 23, 889.

33. Stacey, G. J. GB 1056268, 1967; Chem. Abstr. 1967, 67, 21812.

34. O’ Mant, D. M. US 3365447, 1968; Chem. Abstr. 1968, 69, 35930.

35. Naoto, I.; Masumi, N.; Hiroshi, A. Jpn. Kokai Tokkyo Koho, JP 60161978, 1985; Chem. Abstr. 1986, 104, 19505 